\title{
Transport of Ammonia in the Rabbit Cortical Collecting Tubule
}

\author{
L. Lee Hamm, D. Trigg, D. Martin, C. Gillespie, and J. Buerkert \\ Renal Division, Department of Medicine, Washington University School of Medicine, and Jewish Hospital, St. Louis, Missouri 63110
}

\begin{abstract}
Nonionic diffusion and diffusion equilibrium of ammonia have been generally accepted as the mechanism of urinary ammonium excretion. However, these characteristics have not been examined directly in vitro. In the present studies, nonionic diffusion and diffusion equilibrium of ammonia were examined in rabbit cortical collecting tubules perfused in vitro. Collected fluid ammonium and $\mathrm{pH}$ were measured in tubules exposed to chemical gradients of $\mathbf{N H}_{3} / \mathrm{NH}_{4}^{+}$. In tubules perfused with an acid perfusate free of ammonia and bathed with solutions containing $\mathrm{NH}_{4} \mathrm{Cl}$, collected fluid ammonia failed to equilibrate across the epithelium except at slow flow rates. The estimated apparent permeability coefficient to $\mathrm{NH}_{3}$ was $\sim 5 \times 10^{-3}$ $\mathrm{cm} / \mathrm{s}$. Predominant nonionic diffusion of $\mathrm{NH}_{3}$, rather than transport of $\mathrm{NH}_{4}^{+}$, was indicated by alkalinization of luminal fluid in tubules exposed to peritubular $\mathrm{NH}_{4} \mathrm{Cl}$ and by the relative influence of peritubular $\mathrm{NH}_{4}^{+}$and $\mathrm{NH}_{3}$ on ammonia entry. In tubules perfused with an acid solution containing $\mathrm{NH}_{4} \mathrm{Cl}$, little loss of ammonium was detectable, indicating a low permeability to $\mathrm{NH}_{4}^{+}$.

In contrast to the restricted diffusion of $\mathrm{NH}_{3}$ in cortical collecting tubules, proximal convoluted tubules exhibited a much higher apparent permeability to $\mathbf{N H}_{3}$. In conclusion, nonionic diffusion of $\mathrm{NH}_{3}$ accounted for most ammonium transport in the proximal convoluted tubule and in the cortical collecting tubule. However, there was relatively restricted diffusion in the collecting tubules; this may account for the failure of whole kidney ammonium excretion to obey quantitatively the predictions of nonionic diffusion and diffusion equilibrium of ammonia.
\end{abstract}

\section{Introduction}

Urinary excretion of ammonium has long been held to occur by nonionic diffusion of ammonia $\left(\mathrm{NH}_{3}\right) . \mathrm{NH}_{3}$ has also been held to be in diffusion equilibrium throughout the renal cortex (1-3), resulting in distribution of ammonium $\left(\mathrm{NH}_{4}^{+}\right)$according to $\mathrm{pH}$. Also, ionic $\mathrm{NH}_{4}^{+}$has been thought to be relatively impermeable in tubular epithelia, resulting in so-called "trapping" of ammonia in acidic tubular fluid. However, the changes in urinary excretion of ammonium with changes in urine $\mathrm{pH}$ and urine flow rate are not always quantitatively those predicted by nonionic diffusion $(4,5)$. This fact has been

Preliminary reports of this work were presented at the 16th meeting of the American Society of Nephrology, December 1983, and appeared in abstract form (1983. Clin. Res. 31:748A).

Received for publication 1 May 1984 and in revised form 24 October 1984.

J. Clin. Invest.

(c) The American Society for Clinical Investigation, Inc. 0021-9738/85/02/0478/08 \$1.00

Volume 75, February 1985, 478-485 attributed to limitation of production of ammonia by the kidney and/or to back diffusion of $\mathrm{NH}_{4}^{+}$out of the tubular lumen. Finite permeability to $\mathrm{NH}_{4}^{+}$has recently been found in a variety of epithelial tissues. In fact, in the fish gill, transport of $\mathrm{NH}_{4}^{+}$predominates over transport of $\mathrm{NH}_{3}(6)$. Recently in the turtle bladder, a model epithelium for the collecting tubule, the permeability to $\mathrm{NH}_{4}^{+}$has been found to be 50 times smaller than the permeability to $\mathrm{NH}_{3}$ (7). Although this permeability difference is large, the permeability to $\mathrm{NH}_{4}^{+}$was hypothesized to account for the limitation of excretion of ammonium in an acid urine. Similar permeability characteristics of the mammalian collecting tubule have not been studied in vitro where control and manipulation of both the luminal and peritubular environment can be accomplished.

Transport of ammonia or ammonium across the collecting tubule has recently gained added importance because of studies defining the segmental handling of ammonia in vivo. Most of renal ammonia production can probably be accounted for by production in the proximal convoluted tubule (8-11). However, luminal ammonia in the superficial distal convoluted tubule is insufficient to account for all of urinary ammonia excretion (9-11). That is, ammonia appears to be lost between the late proximal superficial tubule and the early distal convoluted tubule. Also, other studies have directly demonstrated ammonia addition into the collecting tubule (11-13). These studies, however, have not defined the mechanism of ammonia entry into the collecting tubule. Ammonia entry might be by nonionic diffusion as has been widely held. However, ammonia might also be entering by transport of $\mathrm{NH}_{4}^{+}(14)$, as has recently been postulated for the turtle bladder (15) and for the thick ascending limb (16).

The present studies were designed to examine ammonia transport in the isolated perfused rabbit cortical collecting tubule. Specifically, ammonia transport in the presence of transepithelial gradients of ammonia is examined. In this fashion the relative permeability to $\mathrm{NH}_{3}$ and $\mathrm{NH}_{4}^{+}$can be determined. As expected, the apparent permeability to ionic $\mathrm{NH}_{4}^{+}$is relatively low. Unexpectedly, however, the apparent permeability to nonionic $\mathrm{NH}_{3}$ is sufficiently low that $\mathrm{NH}_{3}$ fails to reach diffusion equilibrium except at low flow rates. Such a diffusion barrier for $\mathrm{NH}_{3}$ equilibration may account for certain in vivo observations that differ from the predictions of nonionic diffusion and diffusion equilibrium of $\mathrm{NH}_{3}$. The findings in the cortical collecting tubule were compared with those of studies in the proximal convoluted tubule of the rabbit studied in a similar fashion. The proximal convoluted tubules exhibited a much higher apparent permeability to $\mathrm{NH}_{3}$.

\section{Methods}

Standard techniques of in vitro microperfusion of isolated cortical collecting tubules and proximal convoluted tubules were used (17). The cortical collecting tubules and nonsurface proximal convoluted 
tubules (probably S2 segment predominantly in that glomeruli were not attached) were dissected from kidneys harvested from normal female New Zealand white rabbits. Tubules were perfused between glass pipettes bathed in a chamber kept at $37^{\circ} \mathrm{C}$. Transepithelial potential was measured between calomel electrodes by using agarose bridges (containing solutions similar to the tubule bathing solutions), which contacted the perfusate and bathing solution. Exhaustively dialyzed [methoxy $\left.{ }^{3} \mathrm{H}\right]$ inulin (New England Nuclear, Boston, MA) was used in the perfusate as a volume marker and to check for bath leaks into the collected fluid. $J_{V}$ (fluid reabsorption) was $<0.1 \mathrm{nl} \mathrm{mm} \mathrm{mm}^{-1}$ $\mathrm{min}^{-1}$ in the collecting tubules. Calculated $J_{V}$ 's in the proximal tubules were variable because of the fast flow rates, small collection pipettes, and minimal bath protein; however, the ratio of perfusion rate to collecting rate was $1.00 \pm 0.01$ (SE, $n=21$ collections).

The bathing solutions contained $20 \mathrm{mM} \mathrm{NaHCO}_{3}, 5 \mathrm{mM} \mathrm{KCl}, 8$ $\mathrm{mM} \mathrm{Na} \mathrm{HPO}_{4}, 2 \mathrm{mM} \mathrm{NaH} \mathrm{PO}_{4}, 1 \mathrm{mM} \mathrm{MgSO}, 5 \mathrm{mM}$ alanine, 5 $\mathrm{mM}$ sodium lactate, $1.2 \mathrm{mM} \mathrm{CaCl}, 8.3 \mathrm{mM}$ glucose, 5 vol \% fetal calf serum, and sufficient sodium chloride to adjust the final osmolality to $300 \pm 5$ mosmol. $0-10 \mathrm{mM}$ ammonium chloride was added to the bathing solutions as specified below in replacement for an equivalent amount of sodium chloride. The perfusion solutions contained $5 \mathrm{mM}$ $\mathrm{KCl}, 8 \mathrm{mM} \mathrm{NaH} \mathrm{PO}_{4}, 2 \mathrm{mM} \mathrm{Na} \mathrm{HPO}_{4}, 1 \mathrm{mM} \mathrm{MgSO}, 8.3 \mathrm{mM}$ glucose, $5 \mathrm{mM}$ sodium lactate, $1.2 \mathrm{mM} \mathrm{CaCl}_{2}$, and sufficient $\mathrm{NaCl}$ to adjust the final osmolality to $300 \pm 5$ mosmol. The high phosphate concentrations serve to buffer $\mathrm{pH}$ changes and to lessen unstirred layer effects (7). In a single series of experiments, as described below, 10 $\mathrm{mM} \mathrm{NH}_{4} \mathrm{Cl}$ was added to the perfusate in substitution for an equivalent amount of sodium chloride. All solutions were gassed with $95 \% \mathrm{O}_{2} /$ $5 \% \mathrm{CO}_{2}$ at $37^{\circ} \mathrm{C}$. (In a single group of experiments, $\mathrm{NaCl}$ substituted for the $\mathrm{NaHCO}_{3}$ in the bath, and both the bath and perfusate were bubbled with $100 \% \mathrm{O}_{2}$.) Final bath $\mathrm{pH}$ was approximately 7.4 and perfusate, $\mathrm{pH}$ 6.1. In a single series of experiments, the bath $\mathrm{pH}$ was raised to approximately 7.64 by increasing the sodium bicarbonate concentration to $40 \mathrm{mM}$ and bubbling with $95 \% \mathrm{O}_{2} / 5 \% \mathrm{CO}_{2}$. In those solutions containing ammonium chloride, ammonium chloride was added after gassing the solution.

The $\mathrm{pH}$ and $\mathrm{PCO}_{2}$ of all final bulk solutions were measured by using an Instrumentation Laboratory, Inc. pH/Blood Gas Analyzer 813 (Lexington, MA). The $\mathrm{pH}$ of the perfusate and collected fluid was measured in some experiments by using single-barrel glass membrane $\mathrm{pH}$ microelectrodes as previously described (18). The $\mathrm{pH}$ electrodes were calibrated with two buffers located by the perfusion apparatus and kept at $37^{\circ} \mathrm{C}$. After a constant perfusion rate was obtained, the $\mathrm{pH}$ electrode was quickly inserted down the collection pipette into the small reservoir of collected fluid near the tubule. The circuit was completed with an agarose bridge in the bathing solution. A Ling electrode was used similarly to correct for any voltage difference between the bath and the reservoir of collected fluid.

The concentration of ammonium in the perfusate and collected fluid was measured using a coulometric microtitration technique (19). The accuracy of this technique has been previously demonstrated (10). For each experiment, ammonium concentration was measured in duplicate in $(a)$ the fluid effluxing from the distal end of the perfused tubule into a collection pipette ("collected fluid") and (b) the perfusate instilled into mock collection pipettes from the perfusion pipette ("perfusate"). (As shown in Fig. 2, the ammonium concentration measured in the perfusate was low $[0.8 \mathrm{mM}]$-compared with that in the collected fluid-but was greater than zero. Because the perfusate is nominally free of any ammonia, the measured perfusate "ammonium" serves as a "blank" control. Therefore, except in Fig. 2 and in those experiments in which $\mathrm{NH}_{4} \mathrm{Cl}$ was added to the perfusate, "collected fluid" ammonium concentration refers to the $\left[\mathrm{NH}_{4}^{+}\right]$measured in the collected fluid minus the mean perfusate $\left[\mathrm{NH}_{4}^{+}\right]$for that experiment.) Tubular flow rate was assessed by measuring the time required to fill constant volume pipettes (10-30 $\mathrm{nl})$. Perfusion flow rate was varied by varying the height of a fluid reservoir connected to the perfusion pipette. With each experiment, collections were made at several flow rates. During experimentation when flow rate was changed, a reequi- libration time of 15-20 min was allowed before collecting fluid for analysis of ammonium or $\mathrm{pH}$.

Calculations. The apparent permeability coefficient to $\mathrm{NH}_{3}$ was calculated as $P_{\mathrm{NH}_{3}}=J_{\mathrm{NH}_{3}}\left[\left(\left[\mathrm{NH}_{3}\right]_{B}-\left[\mathrm{NH}_{3}\right]_{L}\right)\right]^{-1}$, where $P_{\mathrm{NH}_{3}}$ is in centimeters per second and $\left[\mathrm{NH}_{3}\right]_{B}$ is the calculated bath $\mathrm{NH}_{3}$ concentration in millimolar. $\left[\mathrm{NH}_{3}\right]_{L}$ is the mean luminal $\left[\mathrm{NH}_{3}\right]$ calculated as the arithmetic mean of the nominal perfusate $\left[\mathrm{NH}_{3}\right]$ (equal to 0 ) and the collected fluid $\left[\mathrm{NH}_{3}\right]$ calculated using $\mathrm{NH}_{3}=(10)^{\mathrm{pH}-9} \times\left[\mathrm{NH}_{4}^{+}\right]$, where $\mathrm{pH}$ and $\left[\mathrm{NH}_{4}^{+}\right]$are the values measured in the collected fluid. This analysis does not consider any contribution of acid or alkaline disequilibrium pH's (see Discussion); our pH measurements should represent equilibrium values. Using the logarithmic mean resulted in little difference. $J_{\mathrm{NH}_{3}}$ is the influx of $\mathrm{NH}_{3}$ calculated as $V_{0} \times\left[\mathrm{NH}_{4}^{+}\right] /(\pi d L)$, where $V_{0}$ is the collection flow rate in nanoliters per minute, $d$ is the tubule diameter (assumed equal to 20 micrometers), $L$ is the tubule length measured by eyepiece micrometer in the perfusion chamber, and $\left[\mathrm{NH}_{4}^{+}\right]$is the collected fluid $\mathrm{NH}_{4}^{+}$concentration. Estimates of $\mathrm{NH}_{4}^{+}$permeability were calculated from experiments examining ammonium exit from the lumen (see below): $P_{\mathrm{NH}}$ $=J_{\mathrm{NH}_{4}}\left[\mathrm{NH}_{4} L-(V F / R T)\left(\mathrm{NH}_{4} L+\mathrm{NH}_{4} B\right) / 2\right]^{-1}$, where $V$ is the measured transepithelial voltage, and $F, R$, and $T$ have their usual meanings. $\mathrm{NH}_{4} L$ is the luminal $\mathrm{NH}_{4}^{+}$concentration $(10 \mathrm{mM})$ and $\mathrm{NH}_{4} B$ is the bath $\mathrm{NH}_{4}^{+}$concentration $(0 \mathrm{mM})$ ). Other calculations are discussed in the Appendix.

Statistics. Results are expressed as means $\pm \mathrm{SE}$ except for $\mathrm{pH}$ values which are given as the $\mathrm{pH}$ of the mean $\left[\mathrm{H}^{+}\right]$. Such results were compared by Student's $t$ test. Linear regression lines were calculated by the method of least squares and compared by analysis of variance of the slopes and intercepts. Where indicated, results were calculated after logarithmic transformation of data. Statistical significance was taken as $P<0.05$.

\section{Results}

Collected fluid ammonia without ammonium chloride addition. Fig. 1 illustrates the collected fluid $\mathrm{NH}_{4}^{+}$concentration in 17 cortical collecting tubules, which were bathed with no ammonium chloride added to the bathing solution. The mean collected fluid ammonium concentration was only $0.72 \pm 0.24$ $\mathrm{mM}$. The collected fluid ammonium concentration was $>1.25$ $\mathrm{mM}$ in only three collections from these 17 tubules. Not shown in Fig. 1 are 13 collections from six proximal convoluted tubules bathed in solutions free of ammonium chloride. The mean collected fluid $\mathrm{NH}_{4}^{+}$was only $0.72 \pm 0.41 \mathrm{mM}$ (mean

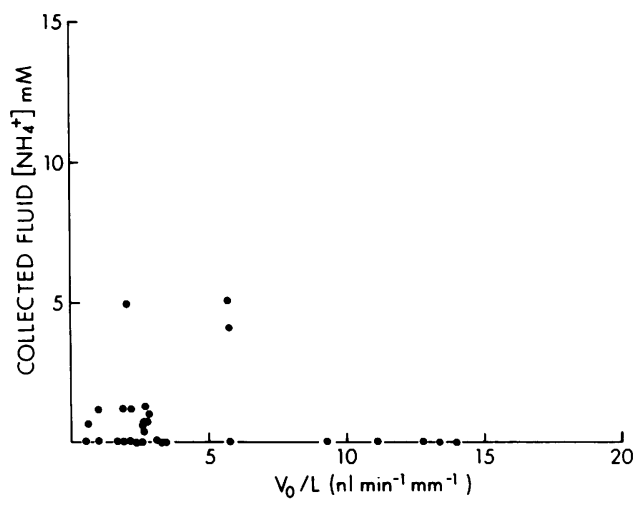

Figure 1. Collected fluid $\mathrm{NH}_{4}^{+}$concentration (in millimolar) as a function of flow rate, factored for tubule length (in nanoliters/minute per millimeter) in cortical collecting tubules bathed in solutions free of added $\mathrm{NH}_{4} \mathrm{Cl}$. Perfusate $\mathrm{pH}$ is 6.17 tubules. In this and al subsequent figures, points represent individual collections. 
flow rate $17 \pm 7 \mathrm{nl} \mathrm{min} \mathrm{mm}^{-1}$ ). Hence, in the conditions of our study, collected fluid ammonium did not represent significant production of ammonia.

Ammonia entry into cortical collecting tubules bathed with $10 \mathrm{mM} \mathrm{NH}_{4} \mathrm{Cl}$. Figs. 2 and 3 show the collected fluid ammonium concentration from six cortical collecting tubules bathed with $10 \mathrm{mM}$ ammonium chloride. Collected fluid ammonium concentration increased in a curvilinear fashion as perfusion rate was slowed (Fig. 2). At the slowest flow rates, the collected fluid $\mathrm{NH}_{4}^{+}$was $\sim 15 \mathrm{mM}$, which is higher than the bath $\mathrm{NH}_{4}^{+}$ concentration. However, at flow rates above $\sim 5 \mathrm{nl} \mathrm{mm} \mathrm{mm}^{-1}$ $\min ^{-1}$, the collected fluid $\mathrm{NH}_{4}^{+}$concentration failed to reach the levels of $\mathrm{NH}_{4}^{+}$in the bath. Considering the buffer capacity of the perfusing solutions (see Appendix) and the collected fluid pH's (see below), this means that $\mathrm{NH}_{3}$ had not reached diffusion equilibrium at the higher flow rates.

To ease comparison with subsequent data, Fig. 3 illustrates the same data as in Fig. 2 except that the horizontal scale is logarithmic. It is apparent that there was an inverse correlation between collected fluid $\mathrm{NH}_{4}^{+}$and the $\log$ of the flow rate $(r=0.94, P<0.01)$. This is the expected relationship for diffusive processes in tubular structures.

If all of the collected fluid $\mathrm{NH}_{4}^{+}$is due to nonionic diffusion of $\mathrm{NH}_{3}$ from the bath, the permeability of these tubules to $\mathrm{NH}_{3}$ can be estimated. The mean apparent permeability coefficient to $\mathrm{NH}_{3}$ in these cortical collecting tubules was $7 \times 10^{-3} \mathrm{~cm} / \mathrm{s}$. The $\mathrm{NH}_{3}$ concentration gradient used to calculate the permeability coefficient included the luminal $\mathrm{NH}_{3}$ concentration, which is a function of measured [ $\left.\mathrm{NH}_{4}^{+}\right]$ and $\mathrm{pH}$. The $\mathrm{pH}$ values used are those discussed below. If the $\mathrm{pH}$ values used in the calculations were falsely low and/or the calculated luminal $\left[\mathrm{NH}_{3}\right]$ low, then the permeability estimate is lower than the true permeability.

Collected fluid $p H$. Fig. 4 shows the collected fluid $\mathrm{pH}$ as a function of flow rate in the same cortical collecting tubules bathed in $10 \mathrm{mM} \mathrm{NH} \mathrm{N}_{4} \mathrm{Cl}$. Collected fluid $\mathrm{pH}$ rose in a curvilinear fashion as the flow rate was lowered. When the cortical collecting tubules were bathed with no ammonium chloride in the bath, the collected fluid $\mathrm{pH}$ remained acidic as indicated by the standard error cross in the lower left corner of Fig. 4. The alkalinization of the luminal fluid in the tubules

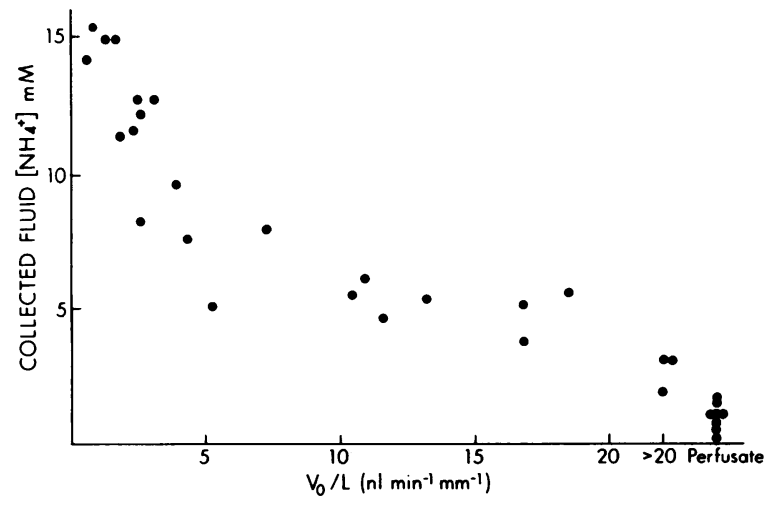

Figure 2. Collected fluid $\mathrm{NH}_{4}^{+}$concentration (in millimolar) as a function of perfusate flow rate (in nanoliters/minute per millimeter) in six cortical collecting tubules bathed in $10 \mathrm{mM}$ ammonium chloride at $\mathrm{pH}$ 7.4. Perfusate $\mathrm{pH}$ was 6 ; measured perfusate $\mathrm{NH}_{4}^{+}$concentration was $0.8 \mathrm{mM}$.

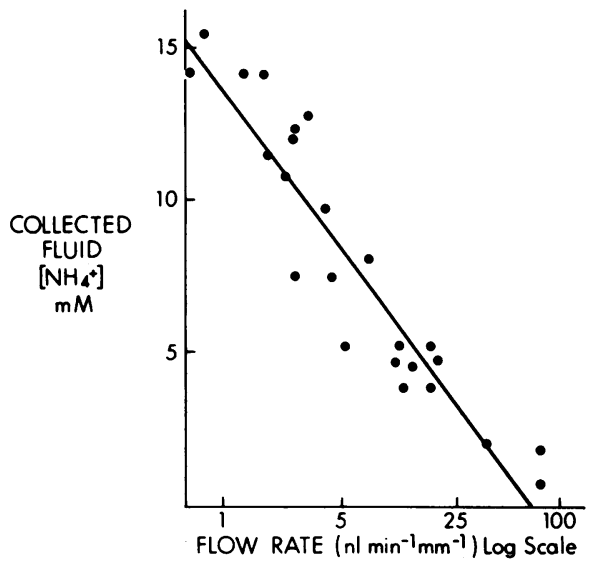

Figure 3. Same data as in Fig. 2 except that collected fluid ammonium concentration is shown as a function of the log of perfusate flow rate and collected fluid $\mathrm{NH}_{4}^{+}$concentration is corrected for the mean perfusate $\mathrm{NH}_{4}^{+}$concentration from the same experiment. The solid line represents the linear regression line calculated by the method of least squares.

bathed in ammonium chloride is consistent with entry of predominantly nonionized $\mathrm{NH}_{3}$, a weak base.

Entry of a given amount of $\mathrm{NH}_{3}$ (which then forms $\mathrm{NH}_{4}^{+}$) will produce an elevation in luminal $\mathrm{pH}$, which can be calculated by knowing the initial pH and buffer content. (The assumptions in these calculations are given in the Appendix.) As shown in Fig. 4, the measured pH values were similar to the values expected from calculations that used the measured collected fluid [ $\left.\mathrm{NH}_{4}^{+}\right]$. Hence, the measured collected fluid $\mathrm{pH}$ and $\left[\mathrm{NH}_{4}^{+}\right]$values were in accord with predominant luminal entry of $\mathrm{NH}_{3}$.

Ammonia exit from the cortical collecting tubule. To examine lumen-to-bath efflux of ammonia from the cortical collecting tubule, $10 \mathrm{mM} \mathrm{NH}_{4} \mathrm{Cl}$ was added to the perfusate

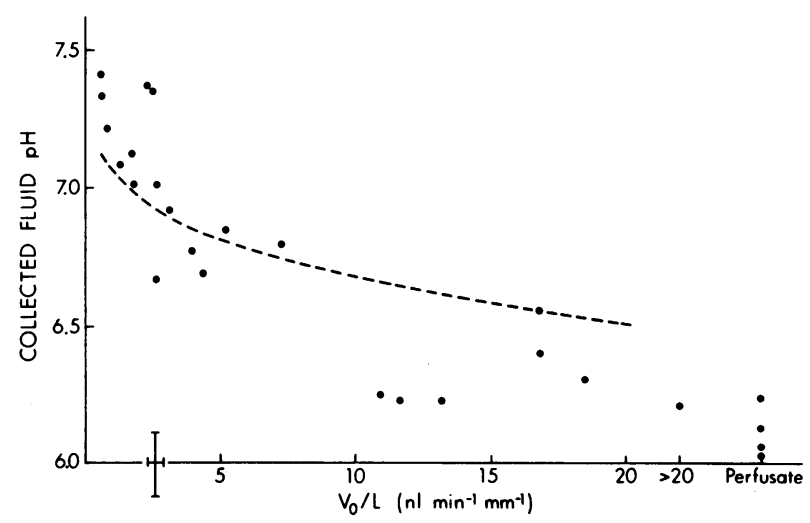

Figure 4. Collected fluid $\mathrm{pH}$ in the six cortical collecting tubules of Fig. 2. Bathing solution is $\mathrm{pH} 7.38$ and contains $10 \mathrm{mM}$ ammonium chloride. The mean perfusate $\mathrm{pH}$ measured in mock collection pipettes was $6.10 \pm 0.04$. The standard error cross on the horizontal axis represents the collected fluid $\mathrm{pH}$ in six measurements in tubules bathed in no ammonium chloride. The dashed line represents the expected collected fluid $\mathrm{pH}$ if all the collected $\mathrm{NH}_{4}^{+}$in Fig. 2 was a result of $\mathrm{NH}_{3}$ transport. (The linear regression line of Fig. 3 was used for these calculations.) See text and Appendix. 
in substitution for an equivalent amount of sodium chloride. As before, the perfusate $\mathrm{pH}$ was 6 . In these experiments, no ammonium chloride was added to the bathing solutions. Fig. 5 illustrates that the collected fluid ammonium concentration in these experiments was nearly the same as that in the perfusate. The mean collected fluid ammonium concentration $(11.24 \pm 0.40 \mathrm{mM})$ was not statistically different from the mean perfusate ammonium concentration $(11.52 \pm 0.51 \mathrm{mM})$. This indicates little passive movement of ionic $\mathrm{NH}_{4}^{+}$across the cortical collecting tubule from lumen to bath; the permeability to $\mathrm{NH}_{4}^{+}$was too low to measure in our experiments.

Collected fluid ammonium with varying peritubular $\mathrm{NH}_{3} /$ $\mathrm{NH}_{4}^{+}$. The alkalinization of collected fluid with peritubular ammonium chloride and the low apparent permeability (lumento-bath) to $\mathrm{NH}_{4}^{+}$are consistent with predominant transport of $\mathrm{NH}_{3}$, not $\mathrm{NH}_{4}^{+}$, with these particular experimental conditions. Predominant transport of $\mathrm{NH}_{3}$ (passive bath-to-lumen) would predict that luminal entry of ammonia would depend predominantly on peritubular $\mathrm{NH}_{3}$ concentration, not $\mathrm{NH}_{4}^{+}$concentration. To examine this prediction, additional cortical collecting tubules were studied at varying concentrations of $\mathrm{NH}_{3}$ and $\mathrm{NH}_{4}^{+}$in the bathing solutions and compared with the prior data presented in Fig. 3. Table I summarizes the bathing solution compositions. $\mathrm{NH}_{4}^{+}$concentrations are, of course, approximately equal to the added total concentration at these $\mathrm{pH}$ values.

Fig. 3 illustrates the relationship between collected fluid ammonium concentration and flow rate (factored for tubular length) in those tubules bathed in $10 \mathrm{mM}$ ammonium chloride at $\mathrm{pH}$ 7.38. This relationship is collected fluid $\mathrm{NH}_{4}^{+}$ $=[13.6 \pm 0.6]-[3.2 \pm 0.3] \times \ln V_{0} / L . V_{0} / L$ represents flow rate factored for tubule length. Fig. 6 illustrates collected fluid ammonium concentration as a function of flow rate in those tubules bathed with $5 \mathrm{mM}$ ammonium chloride at a measured mean bath $\mathrm{pH}$ of 7.37. In these tubules both the $\mathrm{NH}_{4}^{+}$ concentration and the $\mathrm{NH}_{3}$ concentration were one-half that in the previous group. In Fig. $6, \mathrm{NH}_{4}^{+}=[6.8 \pm 0.5]-[2.4 \pm 0.5]$ $\times \ln V_{0} / L(r=0.80, P<0.01)$. The intercept but not the slope of this relationship was statistically different from the data with $10 \mathrm{mM}$ ammonium chloride. The mean apparent

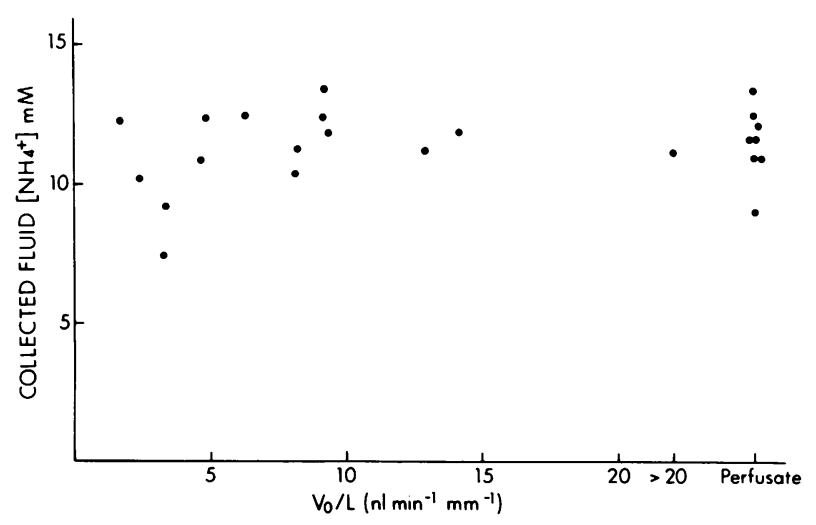

Figure 5. Perfusate and collected fluid $\mathrm{NH}_{4}^{+}$concentration (in millimolar) as a function of perfusate flow rate in four cortical collecting tubules perfused with a solution at $\mathrm{pH} 6$ containing $10 \mathrm{mM} \mathrm{NH}_{4}^{+}$. Mean perfusate and collected fluid $\mathrm{NH}_{4}^{+}$concentration were not statistically different $(11.52 \pm 0.51 \mathrm{mM}$ and $11.24 \pm 0.40 \mathrm{mM}$, respectively).
Table I. Bathing Solution Composition

\begin{tabular}{cll}
\hline $\mathrm{NH}_{4} \mathrm{Cl}$ & Measured mean $\mathrm{pH}$ & Calculated $\mathrm{NH}_{3}$ concentration \\
\hline$m M$ & & $m M$ \\
10 & 7.38 & 0.24 \\
5 & 7.37 & 0.12 \\
5 & 7.64 & 0.22 \\
\hline
\end{tabular}

*Using $\mathrm{pK}_{\mathrm{a}}=9.0$.

permeability coefficient to $\mathrm{NH}_{3}$ calculated as above in these tubules was $4 \times 10^{-3} \mathrm{~cm} / \mathrm{s}$. Also, the collected fluid $\mathrm{pH}$ was measured in four tubules bathed with $5 \mathrm{mM} \mathrm{NH}_{4} \mathrm{Cl}$. The $\mathrm{pH}$ values again demonstrated alkalinization of luminal fluid at slower flow rates although the magnitude was less than with $10 \mathrm{mM} \mathrm{NH}_{4} \mathrm{Cl}$ in the bath. The maximum collected fluid $\mathrm{pH}$ values were $6.6-6.75$ at flow rates of $1-2 \mathrm{nl} \mathrm{mm}^{-1} \mathrm{~min}^{-1}$. The correlation with the predicted $\mathrm{pH}$ (based on the collected fluid $\mathrm{NH}_{4}^{+}$) was similar to that of Fig. 4.

Fig. 7 illustrates the collected fluid ammonium concentration in tubules bathed with $5 \mathrm{mM}$ ammonium chloride at a bath $\mathrm{pH}$ of 7.64. $\mathrm{NH}_{4}^{+}=[11.3 \pm 0.9]-[2.7 \pm 0.6] \times \ln V_{0} / L$ ( $r=0.75, P<0.01)$. The intercept is significantly different from both of the prior two groups. Note, however, that the difference between the two groups bathed in $5 \mathrm{mM}$ ammonium chloride is nearly twofold greater than the difference between the two groups bathed with a similar $\mathrm{NH}_{3}$ concentration. Therefore, qualitatively ammonia entry appears to be predominantly dependent on bath $\mathrm{NH}_{3}$, not $\mathrm{NH}_{4}^{+}$.

Note that the data in both Figs. 6 and 7 indicate that collected fluid $\mathrm{NH}_{4}^{+}$concentration again fails to reach the level in the bathing solution at faster flow rates. If only $\mathrm{NH}_{3}$ equilibrated across the tubules and no other mechanisms of a change in luminal $\mathrm{pH}$ occurred (see Appendix), the predicted equilibrium luminal $\mathrm{NH}_{4}^{+}$values are $16.6,12.1$, and $15.9 \mathrm{mM}$ for the data of Figs. 3, 6, and 7, respectively.

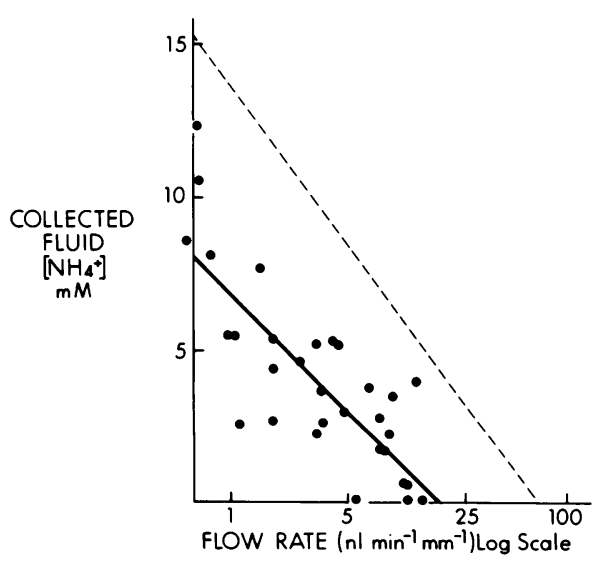

Figure 6. Collected fluid $\mathrm{NH}_{4}^{+}$concentration (in millimolar) as a function of flow rate in eight cortical collecting tubules bathed with 5 $\mathrm{mM}$ ammonium chloride at $\mathrm{pH}$ 7.4. The solid line is the linear regression line. The dotted line represents the linear regression from Fig. 3 for comparison. Details of the two lines are in the text. Initial perfusate $\mathrm{pH}$ was 6 in both cases. 


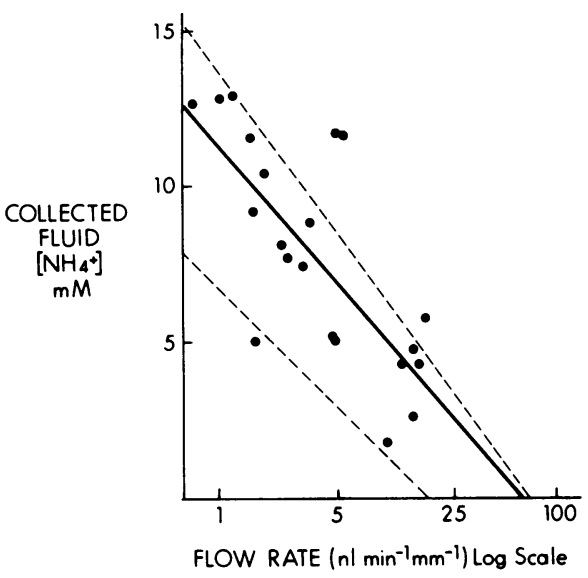

Figure 7. Collected fluid $\mathrm{NH}_{4}^{+}$concentration (in millimolar) vs. flow rate in five cortical collecting tubules bathed with $5 \mathrm{mM} \mathrm{NH}_{4} \mathrm{Cl}$ at pH 7.64. The solid line represents the linear regression line calculated from least squares, the top dashed line represents the linear regression line from Fig. 3 and the bottom dashed line is from Fig. 6. Details of these lines are in the text. Perfusate $\mathrm{pH}$ was again 6.

Ammonia entry into cortical collecting tubules in the absence of $\mathrm{HCO}_{3}^{-} / \mathrm{CO}_{2}$. Nonionic diffusion of $\mathrm{NH}_{3}$ into the tubular lumen will consume protons, $\mathrm{H}^{+}$; the extent of the rise in luminal $\mathrm{pH}$ will depend on luminal buffers. Also, because the luminal $\mathrm{pH}$ will determine the $\mathrm{NH}_{3} / \mathrm{NH}_{4}^{+}$ratio, diffusion of $\mathrm{NH}_{3}$ down a chemical gradient from bath to lumen will depend on luminal buffers. Fig. 8 shows collected fluid ammonium concentration in cortical collecting tubules perfused and bathed in solutions nominally free of $\mathrm{HCO}_{3}^{-}$and $\mathrm{CO}_{2}$. The bath was pH 7.19 and contained $10 \mathrm{mM} \mathrm{NH}_{4} \mathrm{Cl}$; the perfusate was $\mathrm{pH}$ 6.2 and contained no $\mathrm{NH}_{4} \mathrm{Cl}$. In the $\mathrm{HCO}_{3}^{-} / \mathrm{CO}_{2}$-free solutions, collected fluid $\mathrm{NH}_{4}^{+}$(as a function of flow rate) was less than in $\mathrm{HCO}_{3}^{-}$-containing solutions (Fig. 3) with the same concentration of $\mathrm{NH}_{4} \mathrm{Cl}$ in the bath-as predicted with nonionic

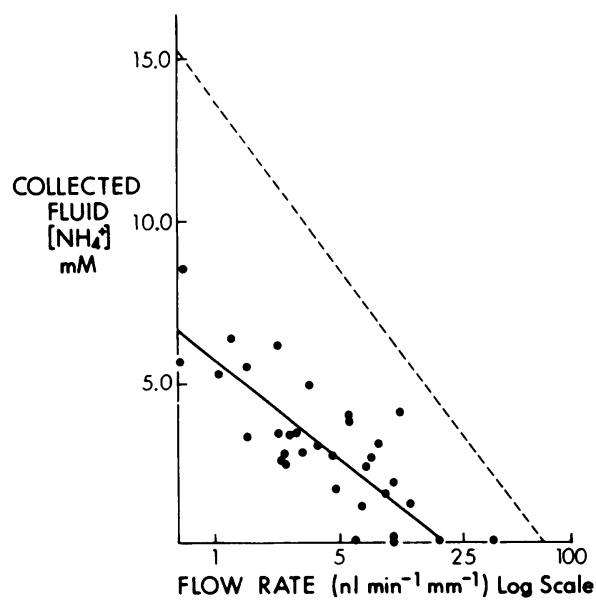

Figure 8. Collected fluid $\mathrm{NH}_{4}^{+}$concentration (in millimolar) vs. flow rate in six cortical collecting tubules bathed with $10 \mathrm{mM} \mathrm{NH}_{4} \mathrm{Cl}$ in the absence of $\mathrm{HCO}_{3}^{-} / \mathrm{CO}_{2}$ in the solutions. The solid line represents the linear regression line calculated from least squares. $\mathrm{NH}_{4}^{+}$

$=[5.5 \pm 0.4]-[1.9 \pm 0.3] \times \ln \frac{V_{0}}{L}(r=0.77, P<0.01)$. The dashed line is for comparison with the data in Fig. 3.

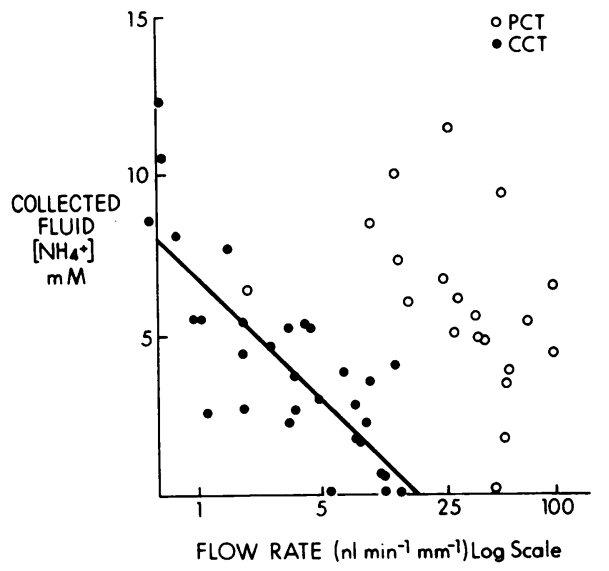

Figure 9. Comparison of collected fluid $\mathrm{NH}_{4}^{+}$concentration in millimolar as a function of flow rate (log scale) in cortical collecting tubules (data of Fig. 6) and five proximal convoluted tubules under the same conditions. Both sets of tubules were bathed with $5 \mathrm{mM}$ $\mathrm{NH}_{4} \mathrm{Cl}$ at $\mathrm{pH}$ 7.4. Perfusate $\mathrm{pH}$ was 6 in both cases.

diffusion. The calculated apparent permeability to $\mathrm{NH}_{3}$ (with the same assumptions as before) was $2 \times 10^{-3} \mathrm{~cm} / \mathrm{s}$. And the collected fluid $\mathrm{NH}_{4}^{+}$again failed to reach the level in the bathing solution at most flow rates. (The predicted equilibrium luminal $\mathrm{NH}_{4}^{+}$value was $6.3 \mathrm{mM}$.) Therefore, these experiments support nonionic diffusion of $\mathrm{NH}_{3}$ and are consistent with restricted diffusion of $\mathrm{NH}_{3}$ even in the absence of $\mathrm{HCO}_{3}^{-} / \mathrm{CO}_{2}$.

Ammonia entry into proximal convoluted tubules bathed with $5 \mathrm{mM}$ ammonium chloride. Fig. 9 compares collected fluid ammonium concentration in proximal convoluted tubules and cortical collecting tubules bathed with $5 \mathrm{mM}$ ammonium chloride at a mean $\mathrm{pH}$ of 7.36. ( $5 \mathrm{mM} \mathrm{NH}_{4} \mathrm{Cl}$ and high flow rates were used in the proximal convoluted tubule because preliminary experiments using $10 \mathrm{mM} \mathrm{NH}_{4} \mathrm{Cl}$ in the bath produced collected fluid $\left[\mathrm{NH}_{4}^{+}\right]$of $13.9 \pm 1.9 \mathrm{mM}$ at flow rates

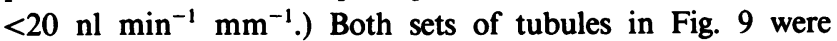

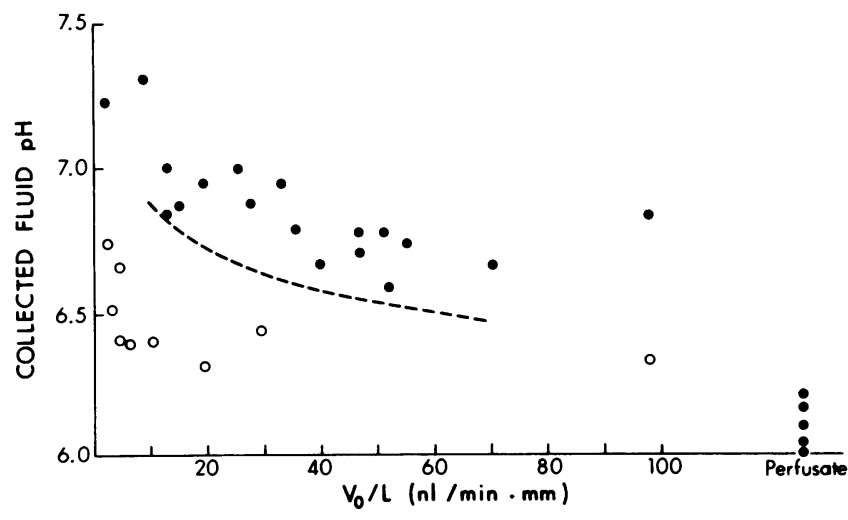

Figure 10. Collected fluid $\mathrm{pH}$ in six proximal convoluted tubules. Bathing solution is pH 7.36 and contains $5 \mathrm{mM} \mathrm{NH}_{4} \mathrm{Cl}(\bullet)$. Collected fluid $\mathrm{pH}$ when no ammonium chloride was in the bath (0). The mean perfusate $\mathrm{pH}$ in mock collection pipettes was $6.11 \pm 0.04$. The dashed line represents the expected collected fluid $\mathrm{pH}$ if the collected fluid $\mathrm{NH}_{4}^{+}$and $\mathrm{pH}$ were solely the result of $\mathrm{NH}_{3}$ transport. The individual values of Fig. 9 (in the range shown) were used to calculate the expected collected fluid $\mathrm{pH}$ values from which the dashed line was derived by the method of least squares. 
perfused with the acidic perfusate. Despite the much higher flow rates used in the proximal convoluted tubules, the collected fluid ammonium concentrations were comparable or higher than in the cortical collecting tubules. Therefore, the proximal convoluted tubule exhibited a much higher apparent permeability to ammonia than the cortical collecting tubule.

Collected fluid $\mathrm{pH}$ in these proximal convoluted tubules (Fig. 10) showed a similar relationship with flow rate (alkalinization with slower flow rates) as that shown in Fig. 4 for cortical collecting tubules except that the points are shifted up and to the right, consistent with a higher $\mathrm{NH}_{3}$ influx. And the collected fluid $\mathrm{pH}$ in those proximal convoluted tubules bathed with $\mathrm{NH}_{4} \mathrm{Cl}$ was higher than in those proximal convoluted tubules bathed without added ammonium chloride. This is again consistent with predominant entry of $\mathrm{NH}_{3}$ into the proximal convoluted tubule. That the measured collected fluid pH was generally higher than that predicted from the measured $\mathrm{NH}_{4}^{+}$concentration may be secondary to passive $\mathrm{pH}$ equilibration across the tubule, due to $\mathrm{HCO}_{3}^{-}$and $\mathrm{H}^{+}$permeability (18).

\section{Discussion}

These studies provide the first direct evaluation of nonionic diffusion of ammonia across the mammalian cortical collecting tubule in vitro. All studies were done using gradients of ammonia across the tubular epithelia, to examine passive permeability properties. These particular studies were not designed to exclude active transport of $\mathrm{NH}_{4}^{+}$. All of our results are consistent with predominant nonionic diffusion of $\mathrm{NH}_{3}$ with little, if any, transport of $\mathrm{NH}_{4}^{+}$. However, our results contrast with previous concepts regarding ammonia transport; namely, equilibration of ammonia across the rabbit cortical collecting tubule was flow rate-dependent and ammonia did not appear to equilibrate except at slow flow rates. Ammonia has previously been thought to be in diffusion equilibrium in the entire renal cortex independent of luminal flow rates (l). Our results also unexpectedly indicate that all tubular epithelia are not equally highly permeable to $\mathrm{NH}_{3}$. Rabbit proximal convoluted tubules and cortical collecting tubules were found to differ markedly in their apparent permeability characteristics to ammonia.

Nonionic diffusion of $\mathrm{NH}_{3}$, diffusion equilibrium of $\mathrm{NH}_{3}$ in all renal cortical structures, and relative impermeability of ionic $\mathrm{NH}_{4}^{+}$have been the principles of our understanding of urinary ammonia excretion (5). In recent years, in vivo studies have greatly enhanced the understanding of segmental ammonium handling by the kidney. However, these studies in general have not evaluated the above principles, which predict that total ammonia concentration (predominantly $\mathrm{NH}_{4}^{+}$at physiologic $\mathrm{pH}$ values) will depend only upon $\mathrm{pH}$ gradients. For example, an intraluminal fluid at a pH of 6.4 would be predicted to have an $\mathrm{NH}_{4}^{+}$concentration 10 -fold higher than an adjacent peritubular fluid having a $\mathrm{pH}$ of 7.4, $\mathrm{NH}_{3}$ concentration being the same in both compartments. On a whole kidney level this would imply that urinary excretion of ammonium would increase linearly with both urine flow rate and urinary hydrogen ion concentration (increase exponentially with a fall in urine $\mathrm{pH}$ ). Quantitatively, these changes in urinary ammonium excretion are not always found with changes in urine flow rate and $\mathrm{pH}(4,5)$. One explanation that is usually discounted is possible inequality of $\mathrm{NH}_{3}$ concentration in adjacent structures. (Medullary $\mathbf{N H}_{3}$ has however been found to be higher than cortical $\mathrm{NH}_{3}$.) However, recent in vivo data suggest that $\mathrm{NH}_{3}$ is lower in the early distal tubule than in the late proximal tubule of superficial nephrons of the rat (20). The present data provide an explanation for both the whole kidney data and the recent in vivo micropuncture data of Simon et al. (20): restricted diffusion of $\mathrm{NH}_{3} .1$

The results of all of the protocols in the cortical collecting tubule were consistent with disequilibrium of $\mathrm{NH}_{3}$ across this epithelium at physiologic to near-physiologic luminal flow rates. $\mathrm{NH}_{3}$ disequilibrium is based on calculated values from the measured collected fluid $\mathrm{NH}_{4}^{+}$and $\mathrm{pH}$. Only if the luminal pH were significantly higher than the measured values, would the calculated luminal $\mathrm{NH}_{3}$ concentration equal that in the bath. Figs. 2, 6, and 7 illustrate that the collected fluid $\mathrm{NH}_{4}^{+}$ did not reach the predicted equilibrium values $(16.6,12.1$, and

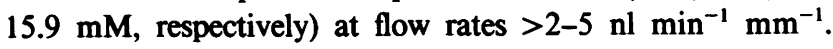
(See Appendix for explanation of "predicted equilibrium values.") And the predicted $\mathrm{NH}_{4}^{+}$concentration would be even higher if net $\mathrm{H}^{+}$secretion or $\mathrm{HCO}_{3}^{-}$reabsorption were considered. Because the physiologic flow rate in vivo in this segment has been estimated to be at least 2-5 $\mathrm{nl} \min ^{-1}(21)$, our data are relevant to the in vivo circumstance.

Restricted diffusion of $\mathrm{NH}_{3}$ is contrary to most prior assumptions regarding ammonia excretion. However, as recently pointed out by Goldstein et al. (6), $\mathrm{NH}_{3}$ is not readily lipidsoluble and therefore may not be readily permeant in all epithelia. In the turtle bladder, Arruda et al. (15), but not Schwartz and Tripolone (7), have found diffusion of $\mathrm{NH}_{3}$ is less than that predicted for an equivalent layer of water, i.e., restricted diffusion. In the collecting tubule, an alkaline disequilibrium pH might cause some component of the apparent restriction to $\mathrm{NH}_{3}$ diffusion. This alkaline disequilibrium $\mathrm{pH}$ could result from $\mathrm{NH}_{3}$ entry into the tubular lumen, which lacks carbonic anhydrase. The apparent $\mathrm{NH}_{3}$ permeability would then underestimate the true $\mathrm{NH}_{3}$ permeability because the luminal $\mathrm{NH}_{3}$ concentration would be higher than that calculated from the collected fluid $\left[\mathrm{NH}_{4}^{+}\right]$and measured equilibrium pH. (Knepper et al. (22) have demonstrated the opposite: an acid disequilibrium $\mathrm{pH}$ from $\mathrm{H}^{+}$secretion that drives ammonia secretion in cortical collecting tubules from deoxycorticosterone-treated rabbits.) However, our experiments in the absence of $\mathrm{HCO}_{3}^{-} / \mathrm{CO}_{2}$ are evidence that other factors probably also contribute to the restricted diffusion of $\mathrm{NH}_{3}$. In the nominal absence of $\mathrm{HCO}_{3}^{-} / \mathrm{CO}_{2}$, any disequilibrium $\mathrm{pH}$ should be small. In any case, restricted diffusion of $\mathrm{NH}_{3}$, whatever the mechanism, is apparent in our experiments.

Although the present studies demonstrated restricted diffusion of $\mathrm{NH}_{3}$ in the cortical collecting tubule, nonionic diffusion of $\mathrm{NH}_{3}$ as a primary mechanism of ammonia transport in this segment was supported. Supporting evidence included the predominant dependence of ammonia entry on bath $\mathrm{NH}_{3}$, not $\mathrm{NH}_{4}^{+}$(Figs. 6 and 7), and the alkalinization of luminal fluid commensurate with higher $\mathrm{NH}_{4}^{+}$concentrations (Fig. 4). The collected fluid did not become more alkaline in the absence of bath $\mathrm{NH}_{4} \mathrm{Cl}$, consistent with relatively low $\mathrm{HCO}_{3}^{-}$ and $\mathrm{H}^{+}$permeabilities in this segment $(23,24)$. If $\mathrm{NH}_{4}^{+}$was the species predominantly transported into the lumen, the

1. These data only address how a $\mathrm{NH}_{3}$ concentration difference is maintained between adjacent tubules and do not address how [ $\left.\mathrm{NH}_{3}\right]$ is lowered between the end proximal tubule and the distal tubule. The loss of ammonia has been postulated to occur by nonionic diffusion from the descending limb of Henle's loop (5) and/or by transport of $\mathrm{NH}_{4}^{+}$in the thick ascending limb (16). 
luminal fluid should have become more acid. The present studies were not designed to exclude some mechanisms of $\mathrm{NH}_{4}^{+}$transport. Specifically, small amounts of active $\mathrm{NH}_{4}^{+}$ transport were not excluded. Such transport has been found in the turtle bladder (15) and other nonmammalian epithelia. However, active transport of $\mathrm{NH}_{4}^{+}$in the turtle bladder, a model epithelium for the collecting tubule, has been disputed (7). Transport of $\mathrm{NH}_{4}^{+}$(via electrical driving forces) has been found in the rat thick ascending limb (16) but not in the collecting tubule (22). Thus, nonionic diffusion of $\mathrm{NH}_{3}$, albeit somewhat restricted, appears to be the primary mechanism of ammonia transport in the cortical collecting tubule.

Passive $\mathrm{NH}_{4}^{+}$transport was also examined in the present studies. Little loss of intraluminal $\mathrm{NH}_{4}^{+}$occurred in tubules perfused with $\mathrm{NH}_{4} \mathrm{Cl}$ and bathed with solutions free of $\mathrm{NH}_{4}^{+}$ (Fig. 5). Also bath-to-lumen movement of $\mathrm{NH}_{4}^{+}$was probably much less than $\mathrm{NH}_{3}$ flux based on the collected fluid $\mathrm{pH}$ values (Fig. 4) and the relative influence of bath $\mathrm{NH}_{4}^{+}$and $\mathrm{NH}_{3}$ on collected fluid $\mathrm{NH}_{4}^{+}$in Figs. 6 and 7. Near-doubling of $\mathrm{NH}_{3}$ concentration with constant $\mathrm{NH}_{4}^{+}$in the bath increased collected fluid $\mathrm{NH}_{4}^{+}$approximately twofold (compare Figs. 6 and 7). Also decreasing $\mathrm{NH}_{4}^{+}$concentration in half while keeping $\mathrm{NH}_{3}$ nearly constant had little effect on collected fluid $\mathrm{NH}_{4}^{+}$, (Fig. 7). ${ }^{2}$ The present data did not exclude some bathto-lumen entry of $\mathrm{NH}_{4}^{+}$. However, the ratio of the calculated permeabilities of $\mathrm{NH}_{3}$ to $\mathrm{NH}_{4}^{+}$was more than was found in the turtle bladder. (Although the apparent $\mathrm{NH}_{4}^{+}$permeability was too low to measure in our "ammonia exit" experiments (see Fig. 5), a maximum $\mathrm{NH}_{4}^{+}$permeability can be estimated and a ratio of $\mathrm{NH}_{3} / \mathrm{NH}_{4}^{+}$permeability of $>100: 1$ can be obtained.) All of this suggests that luminal entry of $\mathrm{NH}_{4}^{+}$per se is less important than $\mathrm{NH}_{3}$ entry, and that $\mathrm{NH}_{4}^{+}$is "trapped" in acidic luminal solutions. Loss of luminal $\mathrm{NH}_{4}^{+}$in this segment (if applicable to other animal species) is an unlikely explanation for the failure of whole-kidney ammonium excretion to quantitatively obey the predictions of nonionic diffusion. ${ }^{3}$

Proximal convoluted tubules exhibited a much higher apparent permeability to ammonia than the cortical collecting

2. Some of the differences between the linear regressions of the 10 $\mathrm{mM} \mathrm{NH}{ }_{4} \mathrm{Cl}$ group and the $5 \mathrm{mM} \mathrm{NH}_{4} \mathrm{Cl}$ at $\mathrm{pH} 7.64$ group (Fig. 7) may be due to the small difference in $\mathrm{NH}_{3}$ concentration $(0.24$ vs. $0.22 \mathrm{mM}$ respectively). Also, unstirred layer-type effects could theoretically contribute to the difference: $(a)$ the higher total ammonia concentration in the first group might provide a higher $\mathrm{NH}_{3}$ concentration at the peritubular surface in the face of continuing ammonia loss from a peritubular unstirred layer; and $(b)$ any $\mathrm{HCO}_{3}^{-}$entry into an unstirred peritubular solution will raise the $\mathrm{pH}$ (and hence $\mathrm{NH}_{3}$ concentration) relatively more in the lower $\mathrm{pH}$ solution (the $10 \mathrm{mM}$ $\mathrm{NH}_{4} \mathrm{Cl}$ group). The tubular cells per se could constitute such an unstirred layer if the apical membrane were the limiting barrier to $\mathrm{NH}_{3}$ diffusion and if the intracellular $\mathrm{pH}$ and ammonia reflected the peritubular solution. Of course, some bath-to-lumen entry of $\mathrm{NH}_{4}^{+}$ could also have caused the small difference in the two groups of studies.

3. The flux ratios of $\mathrm{NH}_{3} / \mathrm{NH}_{4}$ will depend not only on the permeability ratio but also on the concentration ratio, which will be a function of $\mathrm{pH}$. At $\mathrm{pH} 7.4,6.8$, and 5, for example, the ratios of $\mathrm{NH}_{4}^{+} / \mathrm{NH}_{3}$ are 40:1, 158:1, and 10,000:1, respectively. If the permeability ratio were exactly 100:1, $\mathrm{NH}_{4}^{+}$flux would equal $\mathrm{NH}_{3}$ flux at $\mathrm{pH}$ 7. However, $\mathrm{NH}_{4}^{+}$flux is not increasing significantly as $\mathrm{pH}$ is lowered; $\mathrm{NH}_{3}$ flux is falling. Also, a lumen-negative transepithelial voltage will lower lumento-bath $\mathrm{NH}_{4}^{+}$flux. Hence, the implications above that $\mathrm{NH}_{4}^{+}$is "trapped" in acidic fluids should still be valid. tubule. Transport of $\mathrm{NH}_{3}$ rather than $\mathrm{NH}_{4}^{+}$was again suggested by the alkalinization of the collected fluid by exposure of the tubules to peritubular $\mathrm{NH}_{4} \mathrm{Cl}$. The apparent permeability coefficient to $\mathrm{NH}_{3}\left(\sim 6 \times 10^{-2} \mathrm{~cm} / \mathrm{s}\right.$ if all the collected fluid $\mathrm{NH}_{4}^{+}$were due to luminal $\mathrm{NH}_{3}$ entry) was approximately the same as the $\mathrm{CO}_{2}$ permeability in the same segment (25) and was actually lower than the apparent permeability coefficient to $\mathrm{H}^{+}(18)$. If the permeability to $\mathrm{NH}_{4}^{+}$were of the same magnitude as to other ions $\left(2-5 \times 10^{-5} \mathrm{~cm} / \mathrm{s}\right)$, then passive $\mathrm{NH}_{3}$ will exceed passive $\mathrm{NH}_{4}^{+}$transport at $\mathrm{pH}$ values $>6$. The findings in the proximal tubules were more compatible with diffusion equilibrium of ammonia than the studies with collecting tubules. However, if ammonia produced is added directly to the luminal fluid as suggested by recent studies (26), then relative delivery of total ammonia to the more distal nephron and to the peritubular solution will depend on the ratio of ammonia production and luminal flow rate, i.e., the resulting luminal concentration. For instance, if flow rate were doubled with constant ammonia production, then luminal ammonia concentration would be reduced in half, and diffusion of $\mathrm{NH}_{3}$ out of the lumen would be reduced in half, assuming equal luminal $\mathrm{pH}$.

In summary, these studies demonstrate that entry of ammonium into the tubular lumen of rabbit cortical collecting tubules was flow rate-dependent and that ammonia did not equilibrate across the epithelium except at slow flow rates. However, transport of ammonium in the collecting tubule occurred predominantly by nonionic diffusion of $\mathrm{NH}_{3}$. The finding of restricted diffusion of $\mathrm{NH}_{3}$ may partially explain the failure of urinary ammonium excretion to quantitatively conform to the predictions of nonionic diffusion. With acidic perfusate in the cortical collecting tubule, little loss of luminal $\mathrm{NH}_{4}^{+}$was detectable. In contrast to the collecting tubule, the apparent permeability to $\mathrm{NH}_{3}$ in the proximal convoluted tubule was much higher $(\sim 10$ times that in the cortical collecting tubule). The results of the present study, however, must be interpreted with recognition of the fact that the rabbit produces less ammonia than other species (rat, dog, and man) (e.g., ref. 27). ${ }^{4}$ In addition, future studies in other nephron segments with the techniques described herein will be necessary to complete the on-going modeling of whole kidney ammonia handling.

\section{Appendix}

With the most simple model of nonionic diffusion of $\mathrm{NH}_{3}$ across the cortical collecting tubule, the equilibrium values of luminal $\left[\mathrm{NH}_{4}^{+}\right]$and $\mathrm{pH}$ can be easily calculated. By equilibrium values, we mean the values that would be reached with diffusion of $\mathrm{NH}_{3}$ at infinitely slow luminal flow rates. These values will be independent of the tubule permeability to $\mathrm{NH}_{3}$ if the following conditions are assumed for this simplified model: (a) no active or passive transport of $\mathrm{NH}_{4}^{+}$per se; (b) no active transport of $\mathrm{NH}_{3}$ per se; $(c)$ no transport of $\mathrm{H}^{+}, \mathrm{HCO}_{3}^{-}$, or other buffers that would change luminal $\mathrm{pH}$ independent of $\mathrm{NH}_{3}$ movement; and $(d)$ equilibration of $\mathrm{CO}_{2}$ across the tubule at these slow flow rates. (The third assumption is known to be wrong; $\mathrm{HCO}_{3}^{-}$ can be reabsorbed or secreted by the cortical collecting tubule. However, in these studies, the rates of ammonia entry are in general higher than the rates of $\mathrm{HCO}_{3}^{-}$transport reported by others.) In our system of only

4. The rabbit can acidify its urine and has been the animal model studied most in vitro, with general applicability to other species. The limitation in ammonia excretion in the rabbit is probably attributable to decreased production (via phosphate-dependent glutaminase) rather than to limited transport (28). However, as always, extrapolation between species should be cautious. 
phosphate and $\mathrm{HCO}_{3}^{-} / \mathrm{CO}_{2}$ buffers, all $\mathrm{NH}_{3}$ entry will titrate the $\mathrm{pH}$ higher and raise $\mathrm{HPO}_{4}^{-2}$ and $\mathrm{HCO}_{3}^{-}$concentrations. At infinitely slow flow rates, luminal $\left[\mathrm{NH}_{3}\right]$ will equal peritubular $\left[\mathrm{NH}_{3}\right]$. Luminal $\mathrm{pH}$ will satisfy Eqs. 1-4.

Bicarbonate:

$\mathrm{pH}=6.1+\log \frac{\left[\mathrm{HCO}_{3}^{-}\right]}{0.03 \times \mathrm{PCO}_{2}} ;$

Phosphate:

$\mathrm{pH}=6.8+\log \frac{\left[\mathrm{HPO}_{4}^{-2}\right]}{\left[\mathrm{H}_{2} \mathrm{PO}_{4}^{-1}\right]} ;$

and because total phosphate is $10 \mathrm{mM}$,

$\mathrm{pH}=6.8+\log \frac{\left[\mathrm{HPO}_{4}^{-2}\right]}{10-\left[\mathrm{HPO}_{4}^{-2}\right]} ;$

Ammonia:

$\mathrm{pH}=9.0+\log \frac{\mathrm{NH}_{3}}{\mathrm{NH}_{4}^{+}} ;$

and because each $\mathrm{H}^{+}$used to form $\mathrm{NH}_{4}^{+}$from the entry of $\mathrm{NH}_{3}$ will titrate $\mathrm{CO}_{2}\left(\mathrm{H}_{2} \mathrm{CO}_{3}\right)$ or $\mathrm{H}_{2} \mathrm{PO}_{4}^{-1}$ to produce additional $\mathrm{HCO}_{3}^{-}$or $\mathrm{HPO}_{4}^{-2}$,

$\mathrm{NH}_{4}^{+}=\left(\mathrm{HCO}_{3}^{-}-\mathrm{HCO}_{3} i^{-}\right)+\left(\mathrm{HPO}_{4}^{-2}-\mathrm{HPO}_{4} i^{-2}\right)$,

where $\mathrm{HCO}_{3} i^{-}$and $\mathrm{HPO}_{4} i^{-2}$ represent the initial concentrations before the entry of $\mathrm{NH}_{3}$. Inasmuch as we assumed luminal $\mathrm{PCO}_{2}$ and $\mathrm{NH}_{3}$ are equal to bath $\mathrm{PCO}_{2}$ and $\mathrm{NH}_{3}$, respectively, at these infinitely slow perfusion rates, luminal $\mathrm{PCO}_{2}$ and $\mathrm{NH}_{3}$ are known. This leaves four equations (1 and 3-5) and four unknowns (pH, $\mathrm{HCO}_{3}^{-}, \mathrm{HPO}_{4}^{-2}$, and $\mathrm{NH}_{4}^{+}$). Hence, equilibrium values can be calculated. For our measured bath $\mathrm{pH}, \mathrm{PCO}_{2}$, and calculated $\mathrm{NH}_{3}$ concentrations, the calculated luminal equilibrium values are $\mathrm{pH}=7.16$ and $\left[\mathrm{NH}_{4}^{+}\right]=16.6 \mathrm{mM}$ for the $10 \mathrm{mM} \mathrm{NH}_{4} \mathrm{Cl}$ bath; $\mathrm{pH}=7.00$ and $\left[\mathrm{NH}_{4}^{+}\right]=12.1 \mathrm{mM}$ for the 5 $\mathrm{mM} \mathrm{NH} 4 \mathrm{Cl}$ bath (bath $\mathrm{pH}$ 7.37).

With a similar approach that uses the above assumptions, the expected collected fluid $\mathrm{pH}$ for a measured collection fluid [ $\left.\mathrm{NH}_{4}^{+}\right]$can be calculated if we assume all $\mathrm{NH}_{4}^{+}$resulted from $\mathrm{NH}_{3}$ diffusion. In this case $\mathrm{PCO}_{2}$ is assumed to be in equilibrium across the tubule, but $\mathrm{NH}_{3}$ is not. However, now $\mathrm{NH}_{4}^{+}$is a measured value and the equations can be solved for pH. These values are discussed earlier in Results.

\section{Acknowledgments}

We thank Dr. Saulo Klahr, Director of the Renal Division of Washington University School of Medicine, St. Louis, Missouri, for critically reading and discussing this manuscript. We also express our appreciation to Ms. Pat Verplancke for her assistance in the preparation of this manuscript.

These studies were supported by grants AM-09976 and AM-07126 from the National Institute of Arthritis, Digestive and Kidney Diseases and American Heart Association grant 88-791. Dr. Hamm is the recipient of a Biomedical Research Support Institutional Grant (51784).

\section{References}

1. Oelert, H., E. Uhlich, and A. G. Hills. 1968. Messungen des Ammoniakdruckes in den corticalen Tubuli der Rattenniere. Pflugers Archiv. 300:35-48.

2. Denis, G., H. Preuss, and R. Pitts. 1964. The $\mathbf{P}_{\mathrm{NH}_{3}}$ of renal tubular cells. J. Clin. Invest. 43:571-582.

3. Stone, W. J., S. Balagura, and R. F. Pitts. 1967. Diffusion equilibrium for ammonia in the kidney of the acidotic dog. J. Clin. Invest. 46:1603-1608.

4. Orloff, J., and R. W. Berliner. 1956. The mechanism of the excretion of ammonia in the dog. J. Clin. Invest. 35:223-235.

5. Pitts, R. F. 1973. Production and excretion of ammonia in relation to acid-base regulation. Handb. Physiol. (Renal Physiol.) 455496.
6. Goldstein, L., J. B. Claiborne, and D. E. Evans. 1982. Ammonia excretion by the gills of two marine teleost fish: the importance of $\mathrm{NH}_{4}^{+}$permeance. J. Exp. Zool. 219:395-397.

7. Schwartz, J. H., and M. Tripolone. 1983. Characteristics of $\mathrm{NH}_{4}^{+}$and $\mathrm{NH}_{3}$ transport across the isolated turtle urinary bladder. $\mathrm{Am}$. J. Physiol. 245:F210-F216.

8. Good, D. W., and M. B. Burg. 1984. Ammonia production by individual segments of the rat nephron. J. Clin. Invest. 73:602-610.

9. Buerkert, J., D. Martin, and D. Trigg. 1983. Segmental analysis of the renal tubule in buffer production and net acid formation. Am. J. Physiol. 244:F442-F454.

10. Buerkert, J., D. Martin, and D. Trigg. 1982. Ammonium handling by superficial and juxtamedullary nephrons in the rat: evidence for an ammonia shunt between the loop of Henle and the collecting duct. J. Clin. Invest. 70:1-12.

11. Sajo, I. M., M. B. Goldstein, H. Sonnenberg, B. J. Stinebaugh, D. R. Wilson, and M. L. Halperin. 1981. Sites of ammonia addition to tubular fluid in rats with chronic metabolic acidosis. Kidney Int. 20:353-358.

12. Sonnenberg, H., S. Cheema-Dhadli, M. B. Goldstein, B. J. Stinebaugh, D. R. Wilson, and M. L. Halperin. 1981. Ammonia addition into the medullary collecting duct of the rat. Kidney Int. 19:281-287.

13. Graber, M. L., H. H. Bengele, E. Mroz, C. Lechene, and E. A. Alexander. 1981. Acute metabolic acidosis augments collecting duct acidification rate in the rat. Am. J. Physiol. 241:F669-F676.

14. Kurtzman, N. A. 1982. Ammonium secretion and urinary acidification. Semin. Nephrol. 2:1-2.

15. Arruda, J. A. L., G. Dytko, and L. Withers. 1984. Ammonia transport by the turtle urinary bladder. Am. J. Physiol. 246:F653F647.

16. Good, D. W., M. A. Knepper, and M. B. Burg. 1984. Ammonia and bicarbonate transport by thick ascending limb of rat kidney. Am. J. Physiol. 247:F35-F44.

17. Burg, M. J., J. Grantham, M. Abramow, and J. Orloff. 1966. Preparation and study of fragments of single rabbit nephrons. Am. J. Physiol. 210:1293-1298.

18. Hamm, L. L., L. R. Pucacco, J. P. Kokko, and H. R. Jacobson. 1984. Hydrogen ion permeability of the rabbit proximal convoluted tubule. Am. J. Physiol. 246:F3-F11.

19. Karlmark, B. 1973. The determination of titratable acid and ammonium ions in picomole amounts. Anal. Biochem. 52:69-82.

20. Simon, E., D. Martin, J. Fritsch, and J. Buerkert. 1984. Distal tubule ammonia entry. Kidney Int. 25:283A. (Abstr.)

21. Peraino, R. A., and W. N. Suki. 1980. Phosphate transport by isolated rabbit cortical collecting tubule. Am. J. Physiol. 238:F358F362.

22. Knepper, M. A., D. W. Good, and M. B. Burg. 1984. Mechanism of ammonia secretion by rabbit cortical collecting ducts: Quantitative considerations. Contrib. Nephrol. (3rd Int. Workshop on Ammoniagenesis). In press.

23. Laski, M. E., D. G. Warnock, and F. C. Rector. 1983. Effects of chloride gradients on total $\mathrm{CO}_{2}$ flux in the rabbit cortical collecting tubule. Am. J. Physiol. 244:F112-F121.

24. Hamm, L. L., L. R. Pucacco, J. P. Kokko, and H. R. Jacobson. 1982. Hydrogen ion permeability of isolated perfused tubules. Kidney Int. 21:234A. (Abstr.)

25. Schwartz, G. J., A. M. Weinstein, R. E. Steele, J. L. Stephenson, and M. B. Burg. 1981. Carbon dioxide permeability of rabbit proximal convoluted tubules. Am. J. Physiol. 240:F231-F244.

26. Nagami, G. T., and K. Kurokawa. 1984. Regulation of ammonia production by isolated mouse proximal tubules perfused in vitro. Kidney Int. 25:280A.

27. Cruz-Soto, M., D. Battle, S. Sabatini, J. A. L. Arruda, and N. A. Kurtzman. 1982. Distal acidification in the rabbit: role of diet and blood pH. Am. J. Physiol. 243:F364-F371.

28. Yu, H. L., R. Giammarco, M. B. Goldstein, B. J. Stinebaugh, and M. L. Halperin. 1976. Stimulation of ammonia production and excretion in the rabbit by inorganic phosphate. J. Clin. Invest. 58:557564. 